\title{
Anatomy education of medical and dental students during COVID-19 pandemic: a reality check
}

\author{
Anjali Singal $^{1}\left[\cdot\right.$ Agam Bansal $^{2} \cdot$ Priti Chaudhary $^{1} \cdot$ Harsimranjit Singh $^{1} \cdot$ Apurba Patra $^{1}$
}

Received: 18 August 2020 / Accepted: 30 October 2020 / Published online: 18 November 2020

๑) Springer-Verlag France SAS, part of Springer Nature 2020

\begin{abstract}
Purpose During this forced down-time of COVID-19 pandemic, shift to virtual anatomy education is the solitary solution to support the learning of students. The purpose of this study was to understand the visible and invisible potential challenges being faced by the 1 st year medical and dental students while attending digital anatomy classes.

Methods The present study was conducted on 81st year medical and dental students who were admitted to their respective college in August 2019 and were willing to participate in the study. A multiple choice close-ended questionnaire regarding their opinion on virtual classes was designed and feedback was taken from the students.

Results Majority (65\%) of the students agreed that they missed their traditional anatomy learning i.e., dissection courses, face to face lectures and interaction with mentors. The students strongly felt the lack of confidence and difficulty in the topics completed without dissections, models, microscopic slides and other modalities. 83\% felt lack of proper gadgets, high-band width and strong internet connections, a potential barrier in their digital learning. Lack of self-motivation was felt by $69 \%$ students.

Conclusions The current situation of anatomy education is not intentional, and is not the long term silver bullet solution for a visual subject like anatomy. Though learners face a lot of challenges, however, a shift to online must be supported at this time of health crisis. As the digital learning may go for indefinite period, the feedback of students may be helpful for relevant and timely modifications in digital anatomy education.
\end{abstract}

Keywords Anatomy education $\cdot$ COVID-19 $\cdot$ Dissection course $\cdot$ Students $\cdot$ Virtual classes

\section{Introduction}

Severe acute respiratory syndrome coronavirus 2 (SARSCoV-2), the culprit for the pandemic COVID-19, first emerged in China, in late 2019 [13]. The World Health Organization (WHO) declared the outbreak as "public health emergency of international concern" on January 30, 2020 and as pandemic on March 11, 2020 [20]. The government of India imposed mandatory lockdown on March 24, 2020 for 21 days which was extended till 31st May. On June 1, 2020 the government started unlocking the country in different phases. All the educational institutes including medical

Anjali Singal

anjali_singal@rediffmail.com

1 Department of Anatomy, All India Institute of Medical Sciences, Bathinda, Punjab 151001, India

2 Department of Internal Medicine, Cleveland Clinic, Cleveland, OHIO, USA colleges are still closed $[8,17]$. The significant concern is to contain the spread of COVID-19. The virus is changing the world and human lives, medical education is no exception.

Anatomy is the foundation stone of medical education from which clinicians develop their clinical skills. Cadaveric dissection is perceived as a signature experience of the discipline [15]. The COVID-19 pandemic imposed unexpected disruption to anatomical education practice as the medical students lost access not only to cadavers, but also to a number of other learning modalities like models, museum specimens, bones and microscopic slides due to lockdown. The digital switchover is the only option at present not only for Indian anatomists but throughout the world and was achieved with least delays $[15,19]$. The pandemic COVID19 is crafting a new episode in the history of anatomy education in India, as this subject has never before been delivered exclusively online or remotely for medical students in the country. This transformation is not easy for students as well as faculty. While each anatomist is unlocking technology to 
deliver best lectures however virtual anatomy learning has its own unescapable teething problems. The present study was proposed to envision the challenges being faced by the medical and dental students during their remote anatomy learning. The authors feel that the present first year medical and dental students are the best to assess this virtual classes system as they have experienced the traditional face to face classes, dissection halls and microscopic laboratories as well and may genuinely associate. The survey was specifically designed to understand the mental and physical learning conditions of students during virtual classes and how these conditions affected their education. As the digital learning may go for unknown period, the feedback of students may help to design future anatomy course for this learning system.

\section{Materials and methods}

Eighty first year medical and dental students (40 medical students from All India Institute of Medical Sciences, Bathinda and 40 dental students from Bhojia Dental College and Hospital Baddi, India) participated in the present study. Though 50 medical and 60 dental students were admitted to their respective medical or dental college in August 2019 however only the students who were willing to partake in study were included.

Each student was explained the objectives of the study telephonically or via e-mail. A multiple choice close-ended questionnaire was designed and emailed to the students (Table 1). The student's feedback was taken after more than 3 months of digital anatomy education. There was complete anonymity of students. Data were collated and analyzed using ms office 2007 excel spreadsheet (Microsoft Corp Redmond, WA, USA) and program SPSS 20.0 (SPSS Inc. Chicago, IL, USA). The students belong to age group from 17-21 years (mean age 19 years; 47 female and 33 male). Out of the 80 students, 20 belonged to rural and 60 to urban area.

\section{Results}

Each student was aware of pandemic COVID-19, however $15 \%$ were not aware that as per WHO, this may be an endemic. As currently all the students are dependent on digital learning, $74 \%$ agreed to be computer friendly enough to handle online learning. Majority of the students (81\%) were using smartphones; $18 \%$ laptop/desktop and only one student was using tablet for the same. Most of them (83\%) felt the lack of proper gadgets, high band width and strong internet connections, a barrier in their current learning process. $80 \%$ felt lack of proper books or study material at their homes.

Majority (65\%) of them missed every aspect of anatomy education i.e., cadaveric lab, face to face lectures, discussion with their classmates and interaction with mentors. $23 \%$ felt lack of cadaveric/histology lab only. Rest of the students felt either the lack of discussion with their classmates $(6 \%)$ or interaction with mentors (6\%). $88 \%$ students accepted that live dissections helped them to understand and grasp the subject more easily. Each student agreed that neuroanatomical study is more interesting with brain specimen in hand. They $(76 \%)$ found it difficult to understand embryology without models. More than half of them (58\%) preferred distance learning by video recorded classes, followed by power-point presentation (30\%) and theoretical write-ups $(12 \%)$.

When asked about their satisfaction level; $8.8 \%$ were fully satisfied whereas other $8.8 \%$ were completely dissatisfied to study via virtual classes; $55 \%$ marked grade 3 for virtual classes. Only $50 \%$ of the students were satisfied with current assessment system. Though uncertainty of concepts and fear of examination were the main forthcoming challenges felt by the students, however $6 \%$ felt no such challenge. $65 \%$ students were aware that body donation program has been suspended by most of the medical institutes because of COVID-19. Mixed views were there for future mode of anatomy learning, if COVID-19 becomes an endemic (may be because of scarcity of cadavers); some say virtual; prosection or recorded dissections.

Majority of the students (68\%) found difficulty in time management and agreed that they were distracted by home comforts or discomforts. Lack of self-motivation was felt by $69 \%$ students. Most of them (90\%) accepted that they missed their real campus environment, companions, cultural and sporting events.

\section{Discussion}

Moving anatomy education from dissection halls, labs, lecture halls to homes in an urgency due to the pandemic COVID-19 presents enormous challenges, both human as well as technical. Invisible walls has come up, diluting the education system and euphoria of campus life in many ways. It is uncertain how far longer the term digital switchover might go. The change is unescapable. Everyone must realize this is not opted by choice, as the social distancing is the only precautionary measure to protect from pandemic COVID-19. Though nobody wishes longer-term campus closures, however only the future will decide the impending of medical education especially of visual subject like anatomy. 
Table 1 Close ended questionnaire for student's feedback

\begin{tabular}{|c|c|c|}
\hline \multicolumn{2}{|l|}{ Age (years) } & \multirow[b]{4}{*}{ Answer } \\
\hline \multicolumn{2}{|l|}{ Gender (male/female) } & \\
\hline \multicolumn{2}{|c|}{ Home town—geographic area (urban/rural) } & \\
\hline Sr. no. & Question & \\
\hline 1 & Are you aware of COVID-19 pandemic? & Yes/no \\
\hline 2 & $\begin{array}{l}\text { Are you aware that as per WHO, COVID-19 may be an } \\
\text { endemic? }\end{array}$ & Yes/no \\
\hline 3 & Are you computer friendly enough to handle online learning? & Yes/no \\
\hline 4 & Which gadget do you use to attend the online classes? & Smart phone/laptop_-desktop/tablet \\
\hline 5 & $\begin{array}{l}\text { Do you feel lack of proper gadgets, high band width and } \\
\text { strong internet connections; a barrier in your current learn- } \\
\text { ing process? }\end{array}$ & Yes/no \\
\hline 6 & Do you feel lack of proper books or study material? & Yes/no \\
\hline 7 & What do you missed the most in online classes/studies? & $\begin{array}{l}\text { Cadaveric/histology lab } \\
\text { Face to face lectures } \\
\text { Discussion with your classmates } \\
\text { Interaction with mentors } \\
\text { All of them }\end{array}$ \\
\hline 8 & $\begin{array}{l}\text { Do live dissections help you to make the subject easy to } \\
\text { grasp comparatively? }\end{array}$ & Yes/no \\
\hline 9 (medical students) & $\begin{array}{l}\text { You have studied upper limb (along with thorax, head and } \\
\text { neck and neuroanatomy partially) with the aid of real } \\
\text { cadaveric dissection classes while lower limb via online } \\
\text { classes, which was easier to grasp? }\end{array}$ & Upper limb/lower limb \\
\hline 10 (dental students) & $\begin{array}{l}\text { You have partially studied head and neck with the aid of } \\
\text { cadaveric dissection or specimens (along with thorax, } \\
\text { abdomen) and the continuing part via virtual classes, which } \\
\text { was easier to grasp? }\end{array}$ & Digital classes/dissections or specimens \\
\hline 11 & $\begin{array}{l}\text { Is microscopic anatomy tough to understand without spotting } \\
\text { slides under microscope? }\end{array}$ & Yes/no \\
\hline 12 & $\begin{array}{l}\text { Is neuroanatomical study more interesting with brain speci- } \\
\text { men in your hand? }\end{array}$ & Yes/no \\
\hline 13 & $\begin{array}{l}\text { Do you find it difficult to understand embryology without } \\
\text { models? }\end{array}$ & Yes/no \\
\hline 14 & $\begin{array}{l}\text { Which mode do you prefer the most for your distance learn- } \\
\text { ing? }\end{array}$ & $\begin{array}{l}\text { Video recorded classes/theoretical write-ups/power-point } \\
\text { presentations }\end{array}$ \\
\hline 15 & Are you satisfied with current assessment system? & Yes/no \\
\hline 16 & $\begin{array}{l}\text { Do you know that due to COVID- } 19 \text { the body donations are } \\
\text { not accepted by medical institutes? }\end{array}$ & Yes/no \\
\hline 17 & $\begin{array}{l}\text { According to you what should be future mode of anatomy } \\
\text { learning, if COVID-19 becomes an endemic (because of } \\
\text { the scarcity of cadavers)? }\end{array}$ & $\begin{array}{l}\text { Virtual dissections/pro-sections/recorded real cadaver } \\
\text { dissections }\end{array}$ \\
\hline 18 & Do you feel distracted by home comforts/discomforts? & Yes/no \\
\hline 19 & Do you find any difficulty in time management? & Yes/no \\
\hline 20 & Do you feel lack of self-motivation in current scenario? & Yes/no \\
\hline 21 & $\begin{array}{l}\text { Do you miss your real college environment, companions, } \\
\text { cultural and sporting events? }\end{array}$ & Yes/no \\
\hline 22 & $\begin{array}{l}\text { Do you find it helpful studying via virtual classes? (Give no. } \\
1-5 \text { ) } 1 \text { is completely dissatisfied and } 5 \text { is fully satisfied }\end{array}$ & $1-5$ \\
\hline 23 & $\begin{array}{l}\text { What forthcoming challenges do you feel, due to these online } \\
\text { studies in the current academic year? }\end{array}$ & Nothing/fear of passing exams/uncertainty of concepts \\
\hline 23 & $\begin{array}{l}\text { What forthcoming challenges do you feel, due to these online } \\
\text { studies in your carrier? }\end{array}$ & $\begin{array}{l}\text { Nothing/missing of some basic which may be helpful in } \\
\text { clinics }\end{array}$ \\
\hline
\end{tabular}


Virtual anatomy education is the only way to continue learning in the current pandemic situation. As students feedback is a powerful tool for gauging opinion concerning the content and delivery of virtual anatomy classes. Thus the present study was planned to attain student's reflection regarding digital anatomical education and to recognize various mental and physical problems being faced by them during this learning process. The students involved in the current study were admitted to their respective medical or dental colleges in August 2019. They attended their traditional theory and practical anatomy classes for almost seven months and digital classes for more than 3 months. As these students experienced both the systems of education, so they may well compare and comment on the problems confronted by them. The information collected may be helpful for significant and timely modifications in digital anatomy education.

\section{Closure of medical institutes and commencement of journey to online anatomy learning amid COVID-19}

Due to pandemic spread and lockdown in entire country, the students were required to return to their homes in different geographical locations, some with restricted or poor internet access particularly in rural and remote areas. In the present study, 25\% students belong to rural area and internet network was a potential barrier for their effective online learning. In the current scenario, the students are dependent on digital learning completely. The anatomist may take it for granted that the students belong to the millennial generation and all are expert in the use of technology-enhanced learning resources [3], so it was important to know if they were actually well versed with the effective use of computers or other gadgets for their learning. Though majority (74\%) were digitally literate however $26 \%$ were not well versed with the technology to attend online classes, hitting extra burden, effort and time to manage their studies. The anatomy educator might also presume that the students are well equipped with gadgets and whatever taught, they are receiving properly. The real situation was that, most of the students were using smart phones for their online learning. In a visual and three dimensional subject like anatomy the small size of smartphone screen may hinder the proper understanding of the subject. It often require to stare closely and lean a lot to see the details which may cause posture problems and strain eyes causing unnecessary health issues in students. As no one has predicted this pandemic, the students were left with this gadget option only, either due to lockdown or financial crunch. Only a few (19\%) of them were using laptop/desktop or tablet for the digital learning. Majority (83\%) felt the lack of proper gadgets, high band width and strong internet connections; a barrier in their current learning.
As the lockdown was unforeseen, the students who belonged to distant places $(80 \%)$ could not manage to get all the books and study material at their homes which further hindered their learning. These physical challenges may sound minor, but the authors feel that for the first time learner of anatomy, it's actually challenging to handle their studies without appropriate books and study material.

\section{Loss of physical exposure of anatomy students to cadaver dissection and anatomical specimens}

Cadaver dissection is an invaluable experience for the improvement of fine motor skills in a stress-free environment [11]. The anatomy dissection hall is where thorough understanding of anatomy is achieved. Now as the students lost access not only to cadavers, but also to a range of other prime learning modalities: pro-sections, models, skeletons etc., majority ( $88 \%)$ of them realized substantial challenge of virtual anatomy classes due to lack of physical exposure to anatomical specimens [10]. In the present survey, all the medical students completed their upper limb study (along with thorax, head and neck, some part of neuroanatomy) during pre-pandemic period i.e., with the aid of cadavers, specimens etc. The gross anatomy of lower limb was completed via virtual classes and the students strongly feel the lack of acquaintance in this part because of no dissections. Majority of the medical and dental students found that live dissections helped them to understand and grasp the subject more easily. Each student agreed that neuroanatomical study is more interesting with brain specimen in hand. The response was actually important as during the implementation of lock down, the students were having their neuroanatomical classes thus they partially covered this part in dissection hall with appropriate brain specimens and its dissections and rest of the part was covered virtually via online classes. The students also faced difficulty in embryology concepts without models.

In our system, we are having video recorded lectures and power-point presentations. The video recorded classes were appreciated by most of the students. They feel free to learn the topic at their own pace and enjoy the ability to pause, rewind and view videos multiple times [10]. Though innovation of virtual resources and upskilling in new tools are the main benefits gained by anatomists, however the decreased student teacher interaction and student engagement was the imperative matter of concern as there is no mandatory online attendance in most of the institutes during COVID-19 [12].

\section{Challenging assessment system}

The chief challenge faced by the anatomy faculty was how to ensure appropriate methods of assessments. Certainly, this is a challenge tackled by any online education course [1, 
$2,14,16]$. Presently in our set-up, formative assessments are given to the students after completion of each topic and the Google form and Google thread platform is being used for the evaluation of student's knowledge. The students are supposed to post their answers in the limited timeframe and the responses are evaluated by faculty. The assessment system was also a point of worry experienced by the students as only half of the students were satisfied with the current system. The students might feel that some of them were attempting the assignments honestly by their own and some may be taking help from books or other study material, which may affect their comparative score. To mitigate the deceitful part, pre-pandemic evaluations may be given more weightage for internal assessment and if the situation allows return of real campus life shortly, anatomists may look for traditional face to face final evaluations. Presently the anatomy faculty is investigating additional methods to ensure security and robust testing of the students.

\section{Challenge for future anatomy students: closure of body donation programs in response to high risk embalming during COVID-19}

Due to global health crisis, besides the impact on anatomy teaching, resources challenge may be the cause of an additional concern, as most of the medical institutes have temporarily suspended the body donor program due to insecurity regarding the risk to COVID-19 exposure [9]. The issue of body donor scarcity may be tackled by introducing more of longer-term preservation techniques, such as plastination with increased 'shelf-life' of specimens and the use of emerging 3D printing technologies to generate anatomical specimens [5]. In the present survey, majority (65\%) of the students were aware that body donation program has been suspended because of COVID-19 risk. Though in the current situation, it is uncertain when and how body donation program will resume however anatomists must realize that when the pandemic will be over, there may be need of raised public awareness for continuing body donation programs $[5,7,18]$.

Mixed views were there from students for future mode of anatomy learning, if COVID-19 becomes an endemic; some say virtual; pre-dissected specimens or recorded dissections will be helpful for the effective learning of the subject. Thus blended teaching methods may be adopted in future for better understanding of anatomy if it is going to be cadaver-less due to pandemic.

\section{Impact on time management and mental wellness of students during online anatomy learning}

Majority of the students (68\%) surveyed found difficulty in time management and agreed that they were distracted by home comforts or discomforts. In the campus all the students with same environment and circumstances have an equality to learning. However technology allows one student to access class from an air-conditioned, hi-speed Wi-Fi home, while another may be trying to find a quiet corner in an overcrowded apartment with jumpy internet. The difficulty in time management may be because of sudden transition from face to face class room learning to technology-enhanced learning, probably it's even more time consuming if internet signals are poor. The students may also be distracted by some online games, notifications, messages, social media etc.

Student's mental wellness is of concern to the academic anatomist, especially during the pandemic. It's noteworthy that in this distant learning environment, the lack of physically present peers and educators may lead some to have negative learning experiences and may impact their individual motivation. The constant media reporting and everchanging circumstances presented by the pandemic further heightened the anxiety of students. Lack of self-motivation was felt by $69 \%$ students in the current survey. While academicians manage with how to deliver anatomy education online, there needs to be a mindfulness that students who had previously experienced dissection of cadavers, attended microscopic laboratories and traditional face to face classes, require support in the transition to learning remotely [4]. Some motivational classes in between may be planned for the mental fitness of students.

\section{Importance of self-study during COVID-19}

Self-study is a significant aspect of effective learning. Undoubtedly, the students could have been in lower difficulty in their anatomy learning during COVID-19, if they had been trained to study by themselves. Self-education becomes even more important when there are no face to face classes and may soothe the wound created in their learning process during this pandemic. Though self-directed learning was already practiced at some institutes during prepandemic period, however it's the high time to recognize its importance.

During COVID-19, online education should offer significant prospects to students to bridge the gap by encouraging and inculcating concern in them. One cannot ensure success without adaptability. The addition of innovative teaching and learning way, like reverse pedagogy i.e., learning before the lectures may be used to engage students in application of their new knowledge and may help them to move to a better autonomy in anatomy education.

The students value campus life very much and the reallife college experience cannot go virtual. Even if an educational institute is successful in conducting its teaching online, there would no good virtual substitutes for actual 
academic exchanges and other campus activities. In the current survey, most of the students (90\%) wished for their pre COVID-19 college life.

Though anatomy educators are working persistently to provide a seamless transition to virtual learning environment, however a list of challenges are being faced by students and educators as well. In the present survey more than half of the students were moderately satisfied with the virtual anatomy classes and 9\% were completely dissatisfied with digital anatomical learning. Anatomy learners need to realize that the present situation has not been about a drive to move anatomy learning online, rather the need to support their learning during this pandemic. Evans et al. (2020) aptly said that the current transition must be viewed as a stop-gap solution and not a permanent switch as students will return in person and no longer be remote [6]. Though nobody is sure when the situation turns normal and the world will enter into much awaited post COVID-19 epoch as no vaccination for this deadly virus is available so far; however students must be reassured that faculty will try to provide post-pandemic opportunities to review cadaveric pre-dissected specimens, surface, radiological anatomy, microscopic slides and if possible even cadaveric dissection of incomplete parts.

The disruption of anatomy education during COVID-19 pandemic should be looked as an opportunity to expand anatomy education beyond traditional face to face lectures to remote learning methods [15]. The educators are fortified to explore all possible teaching methods to offer improvements and develop innovations in anatomy teaching and evaluation system during this period. It is envisioned that anatomy education will not be same as it was during pre-pandemic period. In the post COVID-19 learning era, though conventional education models will not become obsolete however blended learning (a combination of traditional classroom and online modes) will be the norm.

\section{Limitation of study}

The limitation of the present study is small sample size and the findings are limited to specific geographic region, however this study makes foundation for future integrated multicountry analysis.

Acknowledgements The authors sincerely thank Mr. Puneet Singal for his help in data analysis.

Author contributions AS: project development, data analysis, manuscript writing. AB: project development, manuscript editing. PC: data collection, data analysis, HS: data collection. AP: manuscript editing.

Funding Nil.

\section{Compliance with ethical standards}

Conflict of interest We have no conflicts of interest.

\section{References}

1. Admiraal W, Huisman B, Pilli O (2015) Assessment in massive open online courses. Electron J e-Learning 13(207):216

2. Admiraal W, Huisman B, Van de Ven M (2014) Self and peer assessment in massive open online courses. Int J High Educ 3:119-128. https://doi.org/10.5430/ijhe.v3n3p119

3. Barry DS, Marzouk F, Chulak-Oglu K et al (2016) Anatomy education for the YouTube generation. Anat Sci Educ 9:90-96

4. Blackley S, Sheffield R (2015) Digital andragogy: a richer blend of initial teacher education in the 21st century. Issues Educ Res 25:397-414

5. Brassett C, Cosker T, Davies DC et al (2020) COVID-19 and anatomy: stimulus and initial response. J Anat 237:393-403. https ://doi.org/10.1111/joa.13274

6. Evans DJ, Bay BH, Wilson TD et al (2020) Going virtual to support anatomy education: a stop gap in the midst of the COVID-19 pandemic. Anat Sci Educ 13:279-283

7. Franchi T (2020) The impact of the COVID-19 pandemic on current anatomy education and future careers: a student's perspective. Anat Sci Educ 13:312-315

8. Gettleman J, Schultz K (2020) Modi orders 3-week total lockdown for all 1.3 billion Indians. The New York Times. ISSN 0362-4331

9. HTA human tissue authority (2020) Body donations: frequently asked questions. Human tissue authority, London, UK; URL: https ://www.hta.gov.uk/faqs/bodydonation. Accessed 18 Jul 2020

10. Kelsey AHCM, McCulloch V, Gillingwater TH et al (2020) Anatomical sciences at the University of Edinburgh: initial experiences of teaching anatomy online. Transl Res Anat. https://doi. org/10.1016/j.tria.2020.100065

11. Krähenbühl SM, Čvančara P, Stieglitz T et al (2017) Return of the cadaver: key role of anatomic dissection for plastic surgery resident training. Medicine (Baltimore) 96(29):e7528. https://doi. org/10.1097/MD.0000000000007528

12. Longhurst GJ, Stone DM, Dulohery K et al (2020) Strength, weakness, opportunity, threat (SWOT) analysis of the adaptations to anatomical education in the United Kingdom and Republic of Ireland in response to the COVID-19 pandemic. Anat Sci Educ https://doi.org/10.1002/ase.1967

13. Lu H, Stratton CW, Tang YW (2020) Outbreak of pneumonia of unknown etiology in Wuhan, China: the mystery and the miracle. J Med Virol 92:401-402. https://doi.org/10.1002/jmv.25678

14. Olt MR (2002) Ethics and distance education: strategies for minimizing academic dishonesty in online assessment. Online J Distance Learn Adm, V(III), Fall. Retrieved from http://www.westg a.edu/ distance/ojdla/fall53/olt53.html. Accessed June 2020

15. Pather N, Blyth P, Chapman JA et al (2020) Forced disruption of anatomy education in Australia and New Zealand: an acute response to the COVID-19 pandemic. Anat Sci Educ 13:284-300

16. Robles M, Braathen S (2002) Online assessment techniques. Delta Pi Epsil J 44:39-49

17. Sharma N, Ghosh D (2020) (eds) "Unlock1": malls, restaurants, places of worship to reopen June 8" NDTV. Retrieved 30 May 2020

18. Singal A, Bansal A, Chaudhary P (2020) Cadaverless anatomy: Darkness in the times of pandemic COVID-19. Morphologie Bull de L'assoc des Anat. https://doi.org/10.1016/j.morph o.2020.05.003 
19. Srinivasan DK (2020) Medical student's perceptions and an anatomy teacher's personal experience using an e-learning platform for tutorials during the COVID-19 crisis. Anat Sci Educ

Publisher's Note Springer Nature remains neutral with regard to jurisdictional claims in published maps and institutional affiliations. 13:318-319

20. Velavan TP, Meyer CG (2020) The COVID-19 epidemic. Trop Med Int Health 25:278-280 